\title{
Analysis of the market structure of long-distance transport vehicles in the context of retrofitting diesel engines with modern dual-fuel systems
}

\section{ARTICLE INFO}

Received: 15 July 2021

Revised: 17 August 2021

Accepted: 12 September 2021

Available online: 15 September 2021

Key words: truck market, fuel supply systems, dual-fuel, RCCI

This is an open access article under the CC BY license (http://creativecommons.org/licenses/BY/4.0/)

\section{Introduction}

The history of dual fuel systems is long, but it has never been popularized. Adapting a diesel engine to a dual-fuel system with additional gaseous fuel is not an easy task. There were many reasons for this: from infrastructure problems to technical problems such as inadequate advancement of original diesel fuel supply systems or problems with valve opening timing overlap and difficulties with methane oxidation by the exhaust gas aftertreatment system, resulting in increased total hydrocarbons (THC) emissions [2]. These are the main reasons why retrofit diesel engines are not popular. The development of electronics led to the popularization of high-pressure injections systems such as Common Rail (CR) and pump injection unit (PD) systems. The technological advances of these systems bring the modern dual fuel solutions (controlled by diesel injection signals) and idea of Reactivity Controlled Compression Ignition (RCCI) power supply back to life. RCCI is an ignition method in which highly reactive fuel is injected directly into the cylinder [1]. It mixes with the air and selfignites, thereby initiating the ignition of poorly reactive fuel, which is delivered via indirect injection to the combustion chamber earlier in the process as shown on Fig. 1.

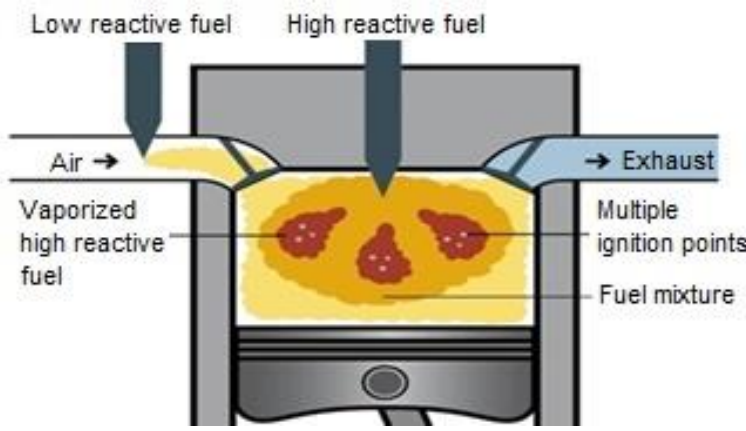

Fig. 1. Ignition and combustion in RCCI engine (based on [18])

The same method of fueling the engine is characteristic of a classic dual-fuel engine, where the difference is that the fuel-air mixture is not homogeneous. The possibility of implementing precise pilot doses and emulating the operation of $\mathrm{CR}$ and $\mathrm{PD}$ injectors opens up new prospects for high rates of replacement $(50-70 \%$ or modern type dualfuel system or $90-99 \%$ for RCCI) of the basic fuel with gaseous fuel in such a system [2, 19]. High replacement coefficient ratios directly affect the benefits of such a solution of fueling a diesel engine, through lower emission of harmful exhaust components [1, 2]. This is significantly different from the systems currently available on the market using simplified versions of dual-fuel systems, which most often use a simplified method of "cutting" diesel doses by emulating the acceleration pedal or manifold absolute pressure (MAP) sensors, as shown in Fig. 2 [20].

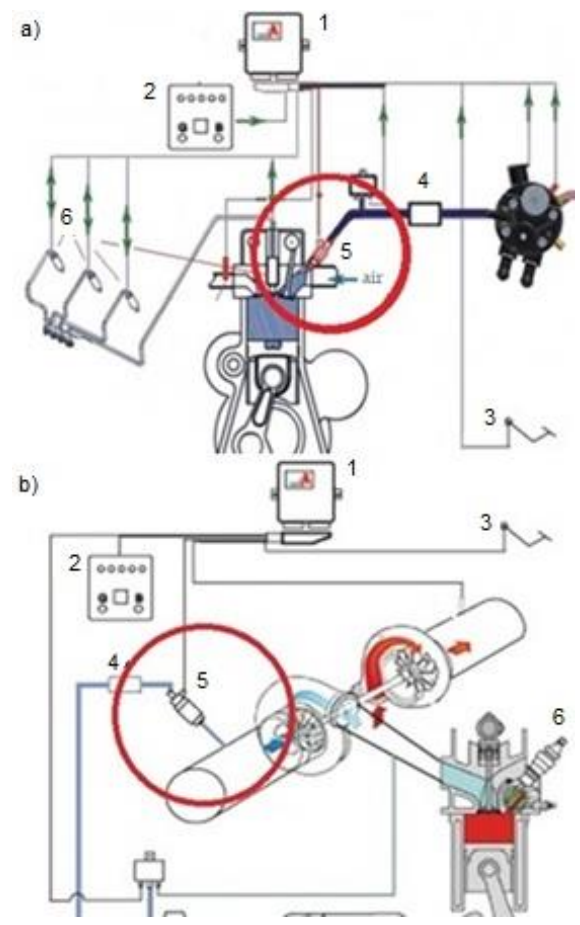

Fig. 2. Comparison of dual fuel systems: a) sequential gas injection preintake valve (controlled by diesel injection signals), b) pre-turbocharger gas injection: 1 - gas ECU, 2 - operation mode switch, 3 - acceleration pedal, 4 - gas filter, 5 - gas injector, 6 - diesel injector (based on $[10,20]$ ) 
Manufacturers of such vehicles offer similar solutions in brand new vehicles, the market of used cars with factory installed systems is quite narrow. Therefore, this work focuses on the analysis of the polish structure of longdistance road transport in the context of the means of transport used by these companies (tractor units) and the possibility of using modern dual-fuel systems in them with the use of the original diesel injection system as a highly reactive fuel dispachers.

\section{The structure and the use of road tractors in the Polish transport companies}

The last report on the long-distance road transport market issued by the Polish Automotive Industry Association indicated that in Poland in 2019, 372.7 thousand road tractors were registered in Poland (data adjusted for vehicles excluded from use in Polish Central Register of Vehicles and Drivers database). The share of the oldest, over 20 years old, amounted to $5 \%$. The youngest - up to four years old reached $30 \%$. Similarly, tractors from five to ten years of age accounted for $30 \%$ of the machine park at the end of 2019. Thus, cars up to 10 years old constitute $60 \%$ of all vehicles. Those from eleven to twenty years remained the most numerous and accounted for $35 \%$ of the fleet. The average age of truck tractors was 8.9 years, with a median of 8 years [3]. At the end of 2019, in the updated part of the park, the number of road tractors registered in Poland was by 88 thousand. greater than the number of registered trucks (complete chassis, not including tractors and special vehicles) with a maximum permissible weight of more than 3.5 tons. For the first time, truck tractors outnumbered trucks in 2015 [3, 5]. This reflects the scale of investments of carriers specializing in international road transport. The year 2020 brought a decrease in sales, in all segments of commercial vehicles weighing more than 3.5 tons. The piling up of a handful of industry problems, led by the pandemic theme, has resulted in one of the worst results in the past few years [17]. Table 1 shows the registrations by manufacturers of new tractor units in 2020, 2019 and 2018 in Poland [6, 17].

Table 1. Registration of new road tractor units in Poland $[6,17]$

\begin{tabular}{|l|l|l|l|}
\hline Brand & 2020 & 2019 & 2018 \\
\hline DAF & 3812 & 5597 & 6358 \\
\hline Scania & 2644 & 5269 & 4901 \\
\hline MAN & 2221 & 4519 & 5295 \\
\hline Volvo & 2644 & 4235 & 4439 \\
\hline Mercedes-Benz & 2226 & 3961 & 3916 \\
\hline Renault & 581 & 1405 & 1734 \\
\hline Iveco & 534 & 382 & 731 \\
\hline Ford Trucks & 146 & 23 & - \\
\hline Total & 14808 & 25391 & 27375 \\
\hline
\end{tabular}

Apart from new trucks, the market structure may also be illustrated by imported used tractor units. In 2020, 29503 used commercial vehicles were imported to Poland, which, however, is a decrease by $6.2 \%$ compared to 2019 (-1948 units), of which 27174 are road tractors - this segment also recorded a decrease by $-3.8 \%(-1,070$ units $y / y)[6,17]$. To illustrate the structure of the demand for used vehicles by their manufacturers (it does not have to be a measure of the real demand for used trucks), data from the search engine were used. The data comes from the portal that sells used trucks in Poland. The data provided is presented in the Fig. 3.

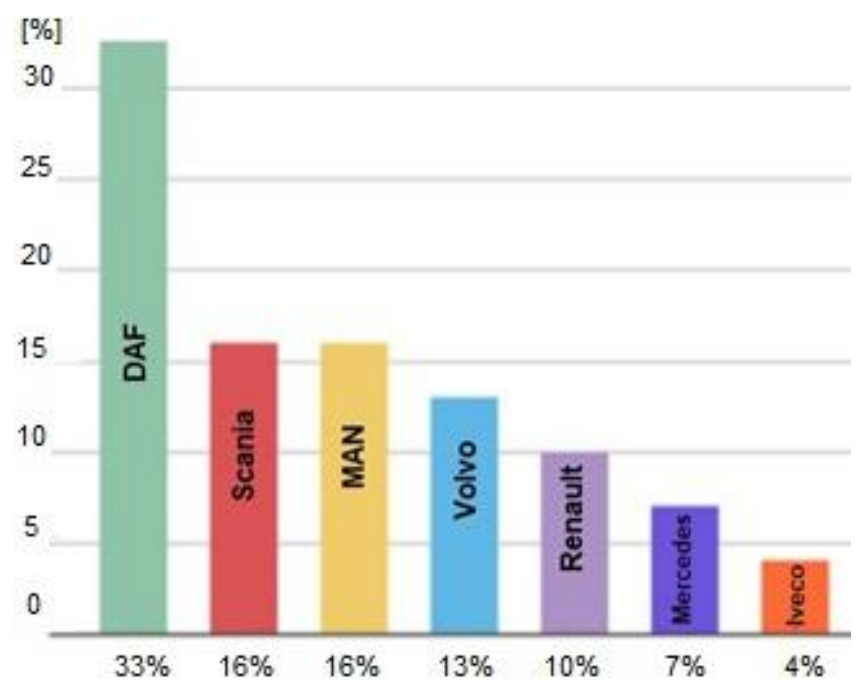

Fig. 3. The popularity of searches by brand for used tractor units [21]

Reliability is an important factor in using truck. Therefore, among the used vehicles, the most popular are road trucks not older than 7 years $[4,9]$. The search data for used tractor units by their year of manufacture may also indicate when selling a vehicle makes the best economic sense. Figure 4 shows the percentage of searches for used tractor units by age.

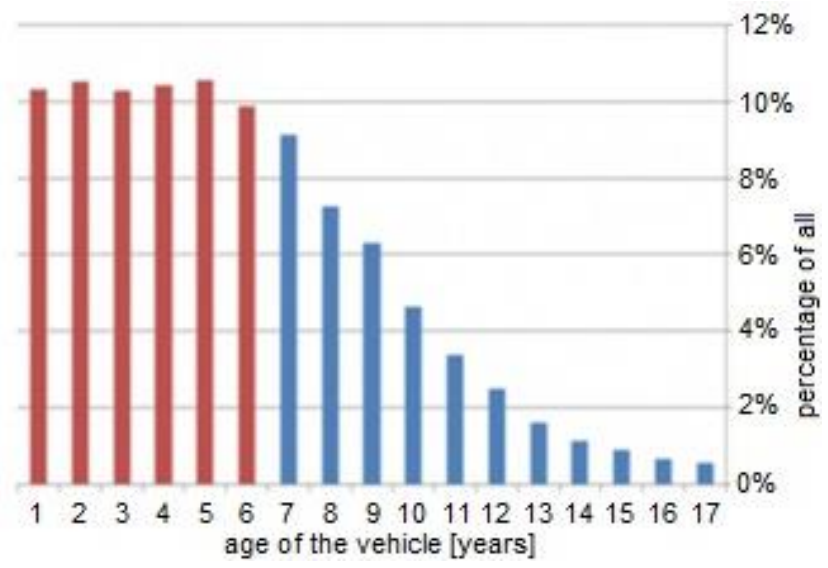

Fig. 4. Searching for used tractor units by their age [21]

Mentioned above data concerning the search preferences for used vehicles according to their year of production are indirectly reflected in the average time of use of a tractor unit in road transport companies. Of course, it is difficult to clearly define the economically justified service life of a tractor unit, as it depends on factors such as the intensity of use, annual mileage, type of work, etc. However, it is assumed that in the case of international longdistance transport it is about 5-7 years, national and local 10-15 years. Vehicles with specialized bodywork are in service the longest. including city ones, incl. garbage 
trucks, sweepers, cranes, concrete pumps, etc. In Poland, there were $44 \%$ of specialist vehicles over 20 years old $[3,6]$.

Summing up, a typical Polish long-distance road transport company uses tractor units of the following brands: DAF, Scania, MAN, Volvo, Mercedes-Benz, Renault, Iveco (Ford Truck due to the beginning of entering the market will be omitted in further considerations) not older than 7 years for transport international or 15 years for domestic transport.

The analysis of the types of fuel supply systems in longdistance vehicle engines, presented in the following paragraph, focuses on the group of trucks mentioned above.

\section{Engines used in road tractors and types of fuel supply systems used in them}

\subsection{DAF [7, 8, 15]}

The Paccar MX engines were introduced in 2006 with XF105 road truck model. They have a displacement 12.9 liters and maximum powers of 408, 462 and 510 horsepower (hp). Thanks to the use of selective catalytic reduction (SCR), they meet the Euro IV or Euro V standards. They have 4 valves per cylinder, turbocharging and charge air cooling. They use single-section PD injection pumps with the pressure increased from 1500 to 2000 bar. As a result, there is no need for a diesel particulate filter in the exhaust system. Successor of the model XF105 in 2014 introduced upgraded Paccar MX engines in two displacement variants. They are 10.8 liters with $440 \mathrm{hp}$ and 12.0 liters with 410 , 460 and $510 \mathrm{hp}$ respectively. Thanks to the use of SCR, they comply with the Euro VI standards. Like the previous engines, they have 4 valves per cylinder, turbo charging and charge air cooling. They use single-section Common Rail injection pumps with a pressure increased from 2,000 to 2,500 bar. As a result, there is no need for a diesel particulate filter in the exhaust system.

\subsection{Scania $[7,8,14]$}

Scania use engines equipped with XPI (short for "extra high-pressure") common-rail fuel system developed in cooperation with Cummins since 2003 in their models of road tractors from series $\mathrm{R}$ and $\mathrm{S}$. These vehicles have a wide range of engines depending on the year of production and the needs of use. These are, respectively, units:

- In-line five-cylinders 9.0 liters 250/280/320/340/360 hp,

- In-line six-cylinders 13.0 liters 370/410/450/480/490 hp,

- V8 16.0 liters 500/520/580/730 hp,

\subsection{MAN [7, 8, 13]}

Models from series TGS and TGX since 2007 are powered by engines of the D20, D26, D36 series with the following power ratings and exhaust standards:

- Euro V with 360 hp, 400 hp, 440 hp, 480 hp, 540 hp and $680 \mathrm{hp}$.

- EURO V EEV (Enhanced Environmentally Friendly Vehicles) with $360 \mathrm{hp}, 400 \mathrm{hp}, 440 \mathrm{hp}, 480 \mathrm{hp}$ and 680 hp.

- Euro VI with 440 hp, 480 hp, 520 hp, 560 hp and 640 hp (the last 3 variants are the new inline 6-cylinder 15.2 liters engine D38).
In the fuel supply system of these units, injection pump systems are used for some units that meet Euro $\mathrm{V}$ and Common Rail Euro V and Euro VI standards.

The TGX series (the most popular long-distance MAN tractor units on the Polish market) uses six-cylinder in-line engines from the MAN D20 (10.5 liters) and D26 (12.4 liters), Euro VI series, in four power ranges: 360 and 400 hp (D20) and 440 and $480 \mathrm{hp} \mathrm{(D26)} \mathrm{obtained} \mathrm{in} \mathrm{the} \mathrm{range}$ of 1600-1800 rpm. In most cases, these trucks have a Common Rail power system.

\subsection{VOLVO Trucks $[7,8,12]$}

In September 2012, Volvo Trucks launched the production of a new generation $\mathrm{FH}$ model with many technical improvements. These tractors use 3 engine variants: D13C (unit injection, and Common Rail after july 2015), D13K (Common Rail), D13TC (Common Rail) in power variants from 360 to $540 \mathrm{hp}$. A variant is also available with the D16 engine with 550,650 or $750 \mathrm{hp}$ and a torque of up to 3550 $\mathrm{Nm}$. All variants powered by CR.

\subsection{Renault Trucks $[7,8,12]$}

The T Series tractor units were presented in 2013 as the first of the new line of vehicles for the company and offers two six-cylinder Euro VI engines, 11.0 liters - DTI11 (380, 430 and $460 \mathrm{hp}$ ) and 13.0 liters DTI13 (440, 480 and 520 $\mathrm{hp})$. All engines are variants taken from previous Premium and Magnum trucks. These are modified Volvo's D series engines. The fuel supply systems used in them are unit injection and Common Rail.

\subsection{Mercedes-Benz Truck [7, 8, 16]}

The Mercedes-Benz Actros MP4 made its debut on 30 September 2011. The fourth version of the Actros model offers several engine options in the Euro V or Euro VI variant. Euro VI uses a six-cylinder in-line engine, both OM471 series with 12.8 liters engines with output power: $422 \mathrm{hp}$ to $530 \mathrm{hp}$ and the OM473 from 15.6 liters engine with output power: $517 \mathrm{hp}$ to $626 \mathrm{hp}$. Both engines use the $\mathrm{X}$-Pulse injection system, which uses the Common Rail system equipped with a system that increases the injection pressure and the function of easy injection modification. The maximum fuel rail pressure is 1160 bar, which makes the maximum injection pressure 2700 bar.

\subsection{IVECO Trucks $[7,8,11]$}

The Stralis model is equipped with 6-cylinder engines with four valves per cylinder. They come in three variants of capacity, achieving different power parameters:

- Cursor 8, 7.8 liters: 310-360 hp

- Cursor 10, 10.3 liters: 420-450 hp

- Cursor 13, 12.9 liters: 500-560 hp

Changes in this engines took place in 2013 with the introduction of new engines meeting the EURO VI exhaust gas standard. All cursor engines after this date use the common rail system.

\section{Discussion}

The demands placed on commercial vehicles are constantly increasing. European legislation has forced commercial vehicle manufacturers to develop ever more powerful and dynamic engines with low fuel consumption. With 
the appearance of exhaust gas purity standards, truck manufacturers realized that it was necessary to improve the fuel supply system so that the combustion process was more efficient. To achieve this, the fuel injected into the cylinders had to be finer in order to mix more easily with air. Highpressure unit injection systems have proved to be a good and reliable solution. They are also relatively cheap to produce and less prone to fuel contamination. Many years and millions of failure-free kilometers traveled on unit injectors effectively distracted some users and producers from the Common Rail system. Exhaust gas standards and increasing consumer expectations forced manufacturers to take another step in their development, i.e. the need for more precise fuel injection control. The development of electronics enabled the creation of PD and CR fuel supply systems, which were designed to reduce emissions and improve the operation of the diesel engine. These systems enable the feeding of the fuel dose in several portions - including the amount of the afterburner - which makes this type of fuel system an advantage in meeting the high requirements of exhaust gas purity for the EURO VI standard. Since all types of diesel fuel are characterized by the so-called delay of ignition the use of a small pilot dose before top dead center (TDC) allows to apply the correct dose to the ignition area of the pilot dose - which makes the engine work softer and quiet while maintaining high thermodynamic efficiency of the engine. The achievements of this technology indicate the potential of its use in a highly effective way, also in modern dual-fuel and RCCI power systems. Adequate control of pilot doses of highly reactive fuel (diesel fuel) to low reactive fuel (gaseous fuel) may be the key to using the original engine fuel supply system for retrofit modifications. Figure 5 shows the theoretical method of implementing such an injection in dual-fuel operation mode.

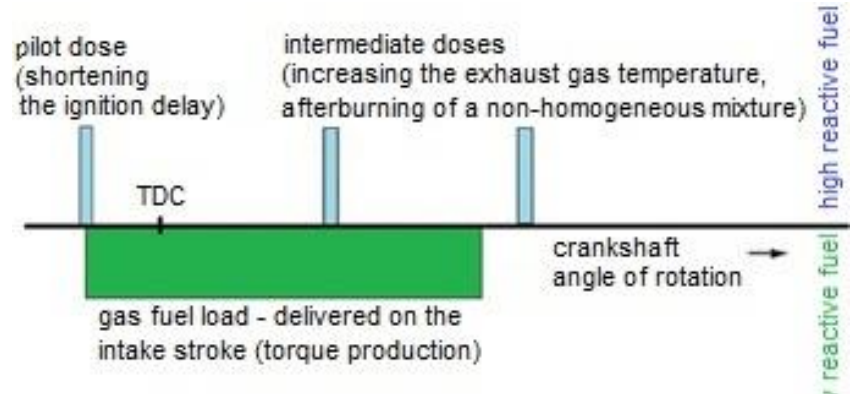

Fig. 5 Diagram of the co-combustion strategy with the use of multiple fuel injection (based on $[1,2,18]$ )

All mentioned above drastically reduce the cost of such a modification, which in turn gives a greater economic justification for the use of such solutions also in used road tractors, exactly like nowadays with the modification of passenger cars for LPG fueling, which is popular in Poland for many years.

The strict emission limits also leave no choice to the producers. The Common Rail system, although more ex- pensive to produce and operate due to very precise cooperating elements, seems to be a solution that will eventually replace other fuel injection solutions in compression ignition engines. There are also electric and hydrogen solutions on the horizon, but at the moment the high energy consumption of road transport does not indicate a quick displacement of self-ignition engines. The future of road tractors' powertrains systems is uncertain. Strict emission limits leave no choice to manufacturers. The Common Rail system, although more expensive in production and operation (due to the very precise cooperating elements), has in principle already replaced and will eventually replace all other conventional fuel injection solutions in self-ignition engines. At least for a while. The overriding goal is to completely postpone the combustion of conventional fossil fuels. Temporarily, it is possible to use dual-fuel and RCCI solutions as less pollutant emitting solutions. At the moment, there is a lot of work on the use of modern dual-fuel or Reactivity Controlled Compression Ignition instead of regular diesel fuel injection only. The conversion to retrofit was successfully made, for example, by Arena Red in a vessel [19] and in more others. There are also electric and hydrogen solutions for truck tractors on the horizon, but at the moment the high energy consumption of road transport does not indicate a quick replacement of compression ignition units with alternative power sources [2].

\section{Conclusion}

- Dual fuel solutions for diesel engines are known, but due to their problems, they never gained popularity.

- New types of dual-fuel installations (originally used in factory vehicles) and Reactivity Controlled Compression Ignition systems can be used as retrofit installations in used vehicles such as Pump injection unit and Common Rail thanks to the use of modern diesel injection systems.

- The structure of the market for long-distance road transport vehicles indicates that the use of vehicles is not older than 7 years for transport international or 15 years for domestic transport. Which indicates the market's readiness (its absorptive capacity) to use modern dual-fuel solutions.

- All road tractors from the group of vehicles used in road transport have injection systems that enable the use of new dual-fuel and Reactivity Controlled Compression Ignition systems.

- Due to the pressure of the legislator and certification, the use of propulsion sources in vehicles is changing. Modern dual-fuel and Reactivity Controlled Compression Ignition releases may, in the factory edition as well as retrofit, prove to be an intermediate link before the full displacement of fossil fuels and their replacement with hydrogen electric powertrains or their combination.

\section{Acknowledgements}

This work was financed by Military University of Technology under research project UGB 880/2021. 


\section{Nomenclature}

CR common rail

ECU Electronic Control Unit

EURO IV, V, VI European emission standards

EN European Norm Standards

MAP manifold absolute pressure
PD pump injection unit

RCCI Reactivity Controlled Compression Ignition

TDC top dead center

THC total hydrocarbons

\section{Bibliography}

[1] GARCIA, A., CARLUCCI, P., MONSALVE-SERRANO, J. et al. Energy management optimization for a power-split hybrid in a dual-mode RCCI-CDC engine. Applied Energy. 2021, 302, 117525.

https://doi.org/10.1016/j.apenergy.2021.117525

[2] HEYWOOD, J.B, Internal Combustion Engine Fundamentals. Second Edition. McGraw-Hill Education. New York 2018.

https://www.accessengineeringlibrary.com/content/book/978 1260116106

[3] KOŹLAK, A. Struktura sektora transportu drogowego w Polsce i ocena jego wyników ekonomicznych na tle państw, Unii Europejskiej. Studia i Prace Kolegium Zarządzania i Finansów. 2018, 166, 59-75.

https://econjournals.sgh.waw.pl/SiP/article/view/805/707

[4] URBANYI-POPIOŁEK, I. Ekonomiczne i organizacyjne aspekty transportu. Wyższa Szkoła Gospodarki w Bydgoszczy. Bydgoszcz 2019.

[5] REPORT of the Polish Central Statistical Office: GUSTransport: wyniki działalności 2019.

[6] REPORT of the Polish Automotive Industry Association: PZPM - Branża motoryzacyjna, raport 2020/2021.

[7] Press data from the manufacturer's website.

[8] Data from diagnostic programs: TEXA Truck version 51.0.0 IDC5 (2021) and Bosch ESI [tronic] 2.0 Truck (2021).

[9] MOBILITY AND TRANSPORT. Road Safety. https://ec.europa.eu/transport/road_safety/specialist/knowled ge/fatique/risk_groups/professional_and_truck_drivers (accessed on 5.09.2021).

[10] SKA-TECH, Auto Gaz Miszewo.

https://eko-pal.com.pl/diesel-na-gaz/ (accessed on 5.09.2021).

Janusz Chojnowski, MSc. - Faculty of Mechanical

Engineering, Military University of Technology,

Poland.

e-mail: janusz.chojnowski@wat.edu.pl
[11] IVECO STRALIS.

https://en.wikipedia.org/wiki/Iveco_Stralis (accessed on 27.08.2021).

[12] List of Volvo Trucks engines.

https://en.wikipedia.org/wiki/List_of_Volvo_Trucks_engines (accessed on 27.08.2021).

[13] MAN TG-range. https://en.wikipedia.org/wiki/MAN_TGX (accessed on 05.09.2021).

[14] Scania series R.

https://en.wikipedia.org/wiki/Scania_series_R (accessed on 27.08.2021).

[15] PACCAR Powertrain.

https://paccarpowertrain.com/engines/mx-13/ (accessed on 5.09.2021).

[16] Daimler Truck AG.

https://roadstars.mercedes-benz-

trucks.com/pl_PL/magazine/transport/03-2014/the-new-om473-the-man-behind-the-engine.html (accessed on 6.09.2021).

[17] Truck Focus.pl.

https://truckfocus.pl/nowosci/58046/podsumowaniesprzedazy-pojazdow-ciezarowych-w-2020-roku (accessed on 3.09.2021).

[18] Arena Red. Engine Management Systems. https://www.arenared.nl/cpbc+ +rcci (accessed on 27.08.2021).

[19] KHL Group Americas LLC.

https://www.dieselgasturbine.com/news/A-Commercial-

First-For-RCCI-Retrofits/7011943.article (accessed on 5.09.2021).

[20] Gascar.pl. http://www.gascar.pl/diesel-na-cng/ (accessed on 3.09.2021).

[21] Getruck.eu. https://www.getruck.eu data obtained courtesy of the portal.

Mirosław Karczewski, DEng. - Faculty of Mechanical Engineering, Military University of Technology, Poland.

e-mail: miroslaw.karczewski@wat.edu.pl 